\title{
The use of Scots pine waste biomass for heating purposes
}

\author{
Maciej Neugebauer ${ }^{1, *}$, Aldona Skotnicka-Siepsiak ${ }^{2}$, Janusz Piechocki $^{1}$, Krzysztof Nalepa $^{1}$, \\ Piotr Sołowiej ${ }^{1}$ \\ ${ }^{1}$ University of Warmia and Mazury in Olsztyn, Faculty of Technical Sciences, 10-719 Olsztyn, M. \\ Oczapowskiego str. 2 \\ ${ }^{2}$ University of Warmia and Mazury in Olsztyn, Faculty of Geodesy, Geospatial and Civil \\ Engineering, 10-719 Olsztyn, M. Oczapowskiego str. 2
}

\begin{abstract}
Scots pine (Pinus Sylvestris) is a very popular tree species in north-eastern Poland. Pines are frequently encountered in allotment gardens in the proximity of residential buildings. Pine biomass should not be composted because the produced humus has acidifying properties. For this reason, the management of pine waste biomass poses a problem. The article proposes a solution for managing pine waste biomass for heat generation. In the study, pine waste biomass was composed of needles, cones and dry branches. The biomass potential of Scots pine was determined. Waste biomass was harvested in spring when most allotment gardens are cleared after winter. The biomass yield of several trees was determined (in $\mathrm{kg}$ and $\mathrm{dm}^{3}$ ), and the average yield per tree was calculated. The average proportions of different biomass fractions in mixed waste biomass were also determined. The specific heat of different biomass fractions (needles, branches, cones) was determined for two scenarios. In the first scenario, waste biomass was harvested during a prolonged dry spell, and in the second scenario, waste biomass was harvested immediately after rainfall. The energy potential of waste biomass was determined. The harvested biomass was burned in an open fireplace in a cottage with an area of $48 \mathrm{~m}^{2}$. The time required to burn $10 \mathrm{~m}^{3}$ of biomass and the resulting increase in indoor temperature were measured. The environmental impact of burning Scots pine biomass was determined.
\end{abstract}

\section{Introduction}

Scots (Pinus Sylvestris) is a common tree species that makes up around $66 \%$ of forest stands in Poland $[1,2]$. It is encountered in forests as well as in residential areas and gardens as an ornamental tree $[3,4]$. Scots pine is a rapidly growing tree species with a high

\footnotetext{
${ }^{*}$ Corresponding author: mak@uwm.edu.pl
} 
annual growth rate [5]. This taxon produces substantial amounts of waste biomass [6] throughout the year, including needles, cones and dry twigs [7, 8]. Biomass management poses a considerable problem in spring when property owners clear their gardens and yards. Large amounts of waste biomass are deposited under trees and have to be raked up. Scots pine biomass should not be composted because it is degraded at a slower rate than other types of biological waste, and the resulting compost (humus) has soil-acidifying properties $[9,10]$. For this reason, pine compost should not be used as fertilizer or organic substrate for ornamental plants and crops. The only exceptions are acid-loving plants such as blueberries and rhododendrons [11]. Therefore, biomass management poses a problem in gardens and plots that are overgrown with pines. However, pine biomass can be used for energy generation $[12,13]$. Pine biomass is composed of small particles with relatively high density and low weight; therefore, the collection and loading of pine biomass to a boiler (fireplace/furnace) can be problematic [14]. Despite the above, large amounts of pine biomass are collected each year during garden cleanup in spring. The use of pine waste biomass for energy production has two benefits: biomass burning generates heat, and the resulting ash constitutes high-quality fertilizer that can be added to other types of composted biological waste $[15,16,17]$.

\section{Aim and scope of the study}

The aim of this study was to test various methods for the effective management of Scots pine biomass for energy generation.

The study had the following limitations:

- the proposed solution should be as simple as possible, it should not require additional equipment or technological processes, and it should be easy to apply in practice;

- the proposed solution should be environmentally-friendly.

The following research tasks were performed during the study:

1. The average quantity of waste biomass produced by one Scots pine in spring was determined;

2. The proportions of different fractions of Scots pine waste biomass were determined;

3. The specific heat capacity of different fractions of dry and wet biomass was calculated;

4. The harvested biomass was burned in a fireplace to heat a building.

\section{Methods}

The waste biomass produced by five Scots pine trees aged around 30 years, with an average height of $10 \mathrm{~m}$, was collected. One of the trees is presented in Figure 1. The experiment was conducted on 8 April 2019, and the quantity of harvested biomass is given in Table 1. The experiment was preceded by three weeks without precipitation, and the obtained biomass was dry (Fig. 2). Wet biomass was harvested on 27 May 2019 after four days of heavy rainfall. Wet biomass was obtained by spreading the previously collected dry biomass on clean ground to prevent contamination with grass and plant matter. Dry biomass was left on the ground on rainy days, and the resulting wet biomass was collected with the use of standard methods. 


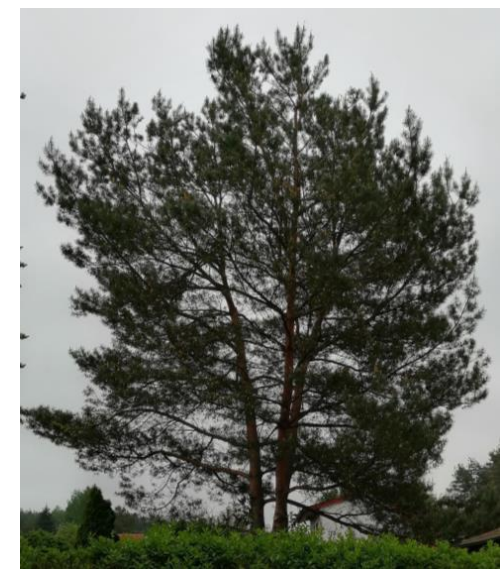

Fig. 1. One of the pines.

Table 1. Quantity of harvested Scots pine biomass.

\begin{tabular}{|c|c|c|c|}
\hline & $\begin{array}{c}\text { Bulk } \\
\text { volume }\end{array}$ & Weight & $\begin{array}{c}\text { Bulk } \\
\text { density }\end{array}$ \\
\hline Tree & {$\left[\mathrm{dm}^{3}\right]$} & {$[\mathrm{kg}]$} & {$\left[\mathrm{kg}^{1} \mathrm{~m}^{-3}\right]$} \\
\hline 1 & 60 & 3.86 & 64.33 \\
\hline 2 & 70 & 4.46 & 63.71 \\
\hline 3 & 60 & 3.78 & 63.00 \\
\hline 4 & 55 & 3.48 & 63.27 \\
\hline 5 & 180 & 11.68 & 64.89 \\
\hline Total & 425 & 27.26 & 64.14 \\
\hline Average per tree & 85 & 5.452 & \\
\hline
\end{tabular}

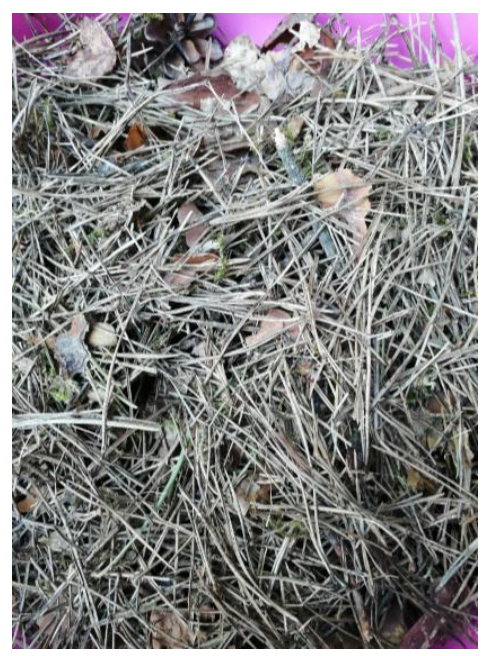

Fig. 2. The collected biomass waste 
The proportions of different fractions (needles, cones, twigs) were determined in five random samples of dry biomass with identical weight. The results were used to determine the average content of each biomass fraction (Table 2). Average standard deviation was calculated in Student's t-test based on the arithmetic mean at the significance level of 0.95. The results are presented in Table 2. Biomass was weighed on the TP60/1 weighing scale with a maximum load of $60 \mathrm{~kg}$ and $20 \mathrm{~g}$ readability.

Table 2. Average content of biomass fractions.

\begin{tabular}{|c|c|c|c|c|c|c|c|}
\hline & & & & Bio & fractions & & \\
\hline & weight & & dles & & & Twi & $\begin{array}{l}5 \mathrm{~mm} \text { in } \\
\text { eter }\end{array}$ \\
\hline $\begin{array}{c}\text { Sample } \\
\text { No. }\end{array}$ & [g] & {$[\mathrm{g}]$} & $\%$ & {$[\mathrm{~g}]$} & $\%$ & [g] & $\%$ \\
\hline 1 & 580 & 320 & 55.2 & 200 & 34.5 & 60 & 10.3 \\
\hline 2 & 620 & 340 & 54.8 & 220 & 35.5 & 60 & 9.7 \\
\hline 3 & 660 & 380 & 57.6 & 240 & 36.4 & 40 & 6.1 \\
\hline 4 & 600 & 300 & 50.0 & 220 & 36.7 & 80 & 13.3 \\
\hline 5 & 620 & 320 & 51.6 & 260 & 41.9 & 40 & 6.5 \\
\hline Average & & & $53.8 \pm 3.5$ & & $37.0 \pm 3.3$ & & $9.2 \pm 3.5$ \\
\hline
\end{tabular}

\section{Analyses and calculations}

In the following stage of the study, pine waste biomass was used to heat a building. Initial air temperature was $15^{\circ} \mathrm{C}-$ measured with HTU21D. A total of 140 liters $(9.12 \mathrm{~kg})$ of dry biomass composed of all harvested fractions was burned. The trial was conducted in an open fireplace in a room with an area of $31.5 \mathrm{~m}^{2}$ and cubic capacity of $66.15 \mathrm{~m}^{3}$. The combustion process proceeded without complications, and very small amounts of smoke were produced (burned biomass had low moisture content).

The temperature inside the room increased by $18^{\circ} \mathrm{C}$ after 5 hours of biomass burning. Air humidity was determined at 55\% with a hygrometer (HTU21D), and the quantity of heat transferred to air was calculated with the use of formulas 1-3.

Air humidity was calculated in kilograms of $\mathrm{H}_{2} \mathrm{O}$ per kilogram of dry air with the use of formula (1):

$$
X=0.622 \cdot \frac{\varphi \cdot P_{A S}}{P-\varphi \cdot P_{A S}}\left[\frac{k g H_{2} O}{k g P S}\right]
$$

where:

$X-$ air humidity $\left[\mathrm{kgH}_{2} \mathrm{O} \cdot \mathrm{kg}\right.$ of Dry $\left.\mathrm{Air}^{-1}\right]$;

$\varphi$ - relative air humidity [-];

$P$ - atmospheric pressure $[\mathrm{Pa}]$;

$P_{A S}$ - partial pressure of water vapor [Pa]. 
The enthalpy of humid air was determined with formula (2):

$$
i=c_{B} \cdot t+\left(c_{A} \cdot t+r_{0}\right) \cdot X\left[k J \cdot \mathrm{kg}^{-1}\right]
$$

where:

$t$ - air temperature $\left[{ }^{\circ} \mathrm{C}\right]$;

$c_{B}$ - specific heat of dry air $\left[\mathrm{kJ} \cdot \mathrm{kg}^{-1} \cdot \mathrm{K}^{-1}\right]$;

$c_{A}$ - specific heat of water vapor $\left[\mathrm{kJ} \cdot \mathrm{kg}^{-1} \cdot \mathrm{K}^{-1}\right]$;

$r_{0}$ - heat of vaporization - determined by air temperature $\left[\mathrm{kJ}^{\cdot} \mathrm{kg}^{-1}\right]$.

The calculations were performed for constant air volume and constant air pressure. It was assumed that heat losses and solar heat gains were negligible. The amount of generated heat was calculated with the use of formula (3):

$$
Q=V \cdot \rho \cdot \Delta i=V \cdot \rho_{1} \cdot i_{1}-V \cdot \rho_{2} \cdot i_{2}[k J]
$$

where:

$Q$ - heat transferred to air during biomass combustion $[\mathrm{kJ}]$;

$\Delta i$ - difference in air enthalpy before and after biomass combustion $\left[\mathrm{kJ}^{\circ} \mathrm{kg}^{-1}\right]$;

$V$ - volume $\left[\mathrm{m}^{3}\right]$;

$\rho_{l}$ and $\rho_{2}-$ air density before and after biomass combustion $\left[\mathrm{m}^{3} \cdot \mathrm{kg}^{-1}\right]$;

Temperature, atmospheric pressure and relative humidity were determined. Air density, heat of vaporization and partial pressure of water vapor are influenced by air temperature; therefore, the respective values were obtained from thermodynamic tables for the measured indoor temperature. The specific heat of dry air $c_{B}$ was adopted at 1.006 $\left[\mathrm{kJ} \cdot \mathrm{kg}^{-1} \cdot \mathrm{K}^{-1}\right]$, and the specific heat of water vapor $c_{A}-$ at $1.862\left[\mathrm{~kJ}^{\circ} \mathrm{kg}^{-1} \cdot \mathrm{K}^{-1}\right]$.

$$
Q=451.7[\mathrm{~kJ}]
$$

Outdoor temperature was equivalent to the initial temperature $\left(15^{\circ} \mathrm{C}\right)$; therefore, it was assumed that the loss of heat from the building to the environment and other unheated premises was negligible.

\section{Results and Discussion}

The combustion trial involved $9.12 \mathrm{~kg}$ of biomass. The total amount of generated heat was calculated based on the average content of different biomass fractions and the calculated heating value. The total heat output was determined at $Q_{c}=185 \mathrm{MJ}$. The energy efficiency of the fireplace where the combustion trial was performed was determined with formula (4):

$$
\eta=\frac{Q}{Q_{c}}=\frac{451.7}{185000}=0.2 \times 10^{-3}
$$

Energy conversion efficiency was very low, which can be attributed to several factors:

1. The loss of heat to the environment and unheated/heated premises in the building was not taken into account in the calculations; 
2. The heat capacity of structural partitions in the building (such as walls) was not taken into account in the calculations;

3. Energy conversion efficiency was determined based on specific heat, and it reflects the overall efficiency of the combustion process. The energy efficiency of a heating device should be calculated based on the calorific value of burned fuel, which is lower that specific heat.

Biomass combustion produced $2.88 \mathrm{~kg}$ of ash. Non-combustible residues accounted for approximately $31 \%$ of burned biomass on a dry weight basis. One kilogram of the collected ash was added to the compost bin, and the remainder was used to fertilize fruit bushes.

\section{Conclusions}

A total of $27.3 \mathrm{~kg}$ of dry Scots pine biomass, including needles, cones and twigs, was harvested for the needs of the study (all waste biomass was collected). Based on the calculated heating value, the potential heat output of pine biomass was determined at $557 \mathrm{MJ}$ of heat, which is equivalent to $22 \mathrm{~kg}$ of coal with a calorific value of $26 \mathrm{MJ} \mathrm{kg}^{-1}$.

The following conclusions can be drawn from the study:

-Dry pine biomass can be used for energy generation:

- The moisture content of biomass harvested after a three-week dry spell was below $15 \%$ in all fractions;

- The heat output of burned biomass was equivalent to that of approximately $22 \mathrm{~kg}$ of coal. Coal can be replaced with waste biomass to heat buildings and decrease carbon dioxide emissions;

- Biomass harvested after a wet spell is characterized by high moisture content and is not suitable for energy generation immediately after collection;

-Pine biomass can be burned to create additional space in compost bins and prolong the period between bin emptying. The resulting compost will not be acidified with pine biomass;

-Each method of managing pine waste biomass on site contributes to the achievement of zero waste goals:

- it is more environmentally friendly than biomass landfilling;

○ it is more environmentally friendly than biomass disposal as organic waste because it reduces the consumption of primary energy associated with biomass transport to conventional landfills and composting plants.

Further research is required to analyze the chemical composition of ash and to determine the optimal method of drying biomass collected in a wet state for energy generation purposes. 


\section{References}

1. Jaroszewicz, B., Różnorodność biologiczna Lasów Polskich, Wszechświat, 108(4-6), 216-221 (2007)

2. Kamiński, W., Rodzime gatunki drzew pótnocno-wschodniej Polski, Pryzmat, Book ISBN: 978-83-934721-9-2, (2016)

3. Harmata, K., Madeja, J., Zemanek, A., Zemanek, B., Wybrane rodzime drzewa $i$ krzewy w polskiej botanicznej literaturze, zwyczajach i sztuce, Wszechświat, 112(1012), 281-291 (2011)

4. Płoszaj-Witkowska, B., Rusek, S., Rozwój i promocja obszarów wiejskich na przykładzie koncepcji ogrodu dla niepetnosprawnych, Barometr Regionalny, 11/1, 8186 (2013)

5. Barzdajn, W., Kowalkowsk,i W., Chmura, D.J., Variation in growth and survival among European provinces of Pinus sylvestris in a 30-year-old experiment, Dendrobiology, 75, 67-77 (2016)

6. Bronisz, K., Bronisz, A., Zasada, M., Bijak, S., Wojtan, R., Tomusiak, R., Dudek, A., Michalak, K., Wróblewski, L., Biomasa aparatu asymilacyjnego $w$ drzewostanach sosnowych zachodniej Polski, Sywan 153(11), 758-767 (2009)

7. Martínez-Vilalta, J., Vanderklein, D. \& Mencuccini, M. Tree height and age-related decline in growth in Scots pine (Pinus sylvestris L.), Oecologia, 150(4), 529-544 https://doi.org/10.1007/s00442-006-0552-7 (2007)

8. Białobok, S., Boratyński, A., Biologia sosny zwyczajnej, Sorus, ISBN 83-85599-21-5. (1993)

9. Puchniarski, T.,H., Sosna Zwyczajna, PWRiL, ISBN 97-88309990-06-2 (2008)

10. Thakur, D., Kausha,1 R., Kulshreshtha, A., Shyam, V., Quality and Microbiological Evaluation of Phosphocompost Prepared from the Hydrothermal Pre-treated Pine Needles using Indigenous Microbial Consortium, J. Ind. Soc. Soil Sci. 65(1), 86-95 (2017)

11. Grajkowski, J., Ochmian, I., Ostrowska, K., Mulińsk,i Z., Wzrost i plonowanie borówki wysokiej (vaccinium corymbosum l.) Odmiany 'sierra' uprawianej na wałach $z$ zastosowaniem trzech podłoży organicznych, Rocz. AR Poz CCCLXXXIII, Ogrodn. 41, 303-308 (2007).

12. Sporek, M., Potencjat energetyczny biomasy sosny zwyczajnej (Pinus sylvestris L.), Proceedings of ECOpole, 7(2), 721-725 (2013)

13. Aniszewska, M., Gendek, A., Porównanie ciepła spalania $i$ wartości opałowej szyszek wybranych gatunków drzew leśnych, Leśne Prace Badawcze 75(3), 231-236 (2014)

14. Demibras, A., Combustion characteristics of different biomass fuels, Progress in Energy and Combustion Science, 30(2), 219-230 (2004)

15. Nunes, L.J.R., Matias, J.C.O., Catalão, J.P.S., Biomass combustion systems: A review on the physical and chemical properties of the ashes, Renewable and Sustainable Energy Reviews, 53, 235-242 (2016)

16. Neugebauer, M., The use of biological waste as a source of low-temperature heat for hotbeds in spring in north-eastern Poland, Journal of Environmental Management, 225, 133-138 (2018)

17. Tortosa Masiá, A.A., Buhre, B.J.P., Gupta, R.P., Wall, T.F., Characterising ash of biomass and waste, Fuel Processing Technology, 88(11-12), 1071-1081 (2007) 